\title{
Effects of ascorbic acid on in vitro culture of bovine preantral follicles
}

\author{
Evelyn R. Andrade ${ }^{1}$, Robert van den Hurk ${ }^{3}$, Lívia A. Lisboa ${ }^{2}$, Mariana F. Hertel ${ }^{2}$, \\ Fabiana A. Melo-Sterza ${ }^{4}$, Kleber Moreno ${ }^{2}$, Ana Paula F. R. L. Bracarense ${ }^{2}$, \\ Fernanda C. Landim-Alvarenga ${ }^{5}$, Marcelo M. Seneda ${ }^{2}$ and Amauri A. Alfieri ${ }^{2}$ \\ Universidade Estadual de Londrina, Londrina, PR, Brazil; Faculty of Veterinary Medicine, Utrecht University, Utrecht, \\ The Netherlands; Universidade Estadual do Mato Grosso do Sul, Aquidauna, MS, Brazil; and Universidade Estadual de São \\ Paulo, Botucatu, SP, Brazil
}

Date submitted: 22.03.2011. Date accepted: 14.06.2011

\section{Summary}

The objective of this study was to evaluate the effects of adding ascorbic acid to the media for in vitro culture of cattle ovarian fragments and to determine their effects on growth activation and viability of early-stage follicles. The ovarian cortex was divided into small fragments; one fragment was immediately fixed (control) and the other fragments were cultured in minimum essential medium (MEM) supplemented or not with various doses of ascorbic acid. Ovarian tissue was processed for histology, transmission electron microscopy (TEM) and immunohistochemical demonstration of proliferating cell nuclear antigen (PCNA). Compared with control fragments, the percentage of primordial follicles was reduced $(p<0.05)$ and the percentage of growing follicles had increased $(p<$ 0.05 ) in cultured cortical fragments, independent of the tested medium or incubation time. Furthermore, compared with control tissue, culture of ovarian cortex for 8 days reduced the percentages of healthy, viable follicles $(p<0.05)$, but not when cultures were supplemented with 25,50 or $100 \mu \mathrm{g} / \mathrm{ml}$ of ascorbic acid. Ultrastructural and immunohistochemical analysis of 8 day cultured ovarian cortical fragments, however, showed the integrity and viability of follicles only when fragments were cultured in presence of $50 \mu \mathrm{g} / \mathrm{ml}$ of ascorbic acid. In conclusion, this study demonstrated that addition of ascorbic acid to MEM at a concentration of $50 \mu \mathrm{g} / \mathrm{ml}$ not only stimulates the activation of 8 day in vitro cultured cattle primordial follicles and subsequent growth of activated follicles, but also safeguards the viability of these early-stage follicles.

Keywords: Ascorbic acid, Cattle, In vitro culture, Preantral follicles

\section{Introduction}

In mammals, the ovary is a heterogeneous organ that contains follicles at various stages of development. In order to produce mature oocytes, follicles are activated from the pool of dormant primordial follicles and

\footnotetext{
${ }^{1}$ All correspondence to Evelyn R. Andrade. Universidade Estadual de Londrina, Londrina, PR, Brazil. Tel: +55 4333015675. e-mail: evelyn_andrade@yahoo.com

${ }^{2}$ Universidade Estadual de Londrina, Londrina, PR, Brazil.

${ }^{3}$ Faculty of Veterinary Medicine, Utrecht University, Utrecht, The Netherlands.

${ }^{4}$ Universidade Estadual do Mato Grosso do Sul, Aquidauna, MS, Brazil.

${ }^{5}$ Universidade Estadual de São Paulo, Botucatu, SP, Brazil.
}

develop through primary and secondary stages before acquiring an antral cavity. At the antral stage, most follicles undergo atretic degeneration, whereas a few follicles grow further and may reach the pre-ovulatory stage under cyclic gonadotropin stimulation, which occurs after puberty (McGee \& Hsueh 2000). The development of in vitro conditions to promote primordial follicle development and the study of early folliculogenesis under in vitro circumstances may be important to reduce follicular demise that usually occurs in vivo. In the last three decades, many researchers have dedicated themselves to this topic using different mammalian species (murine: Gao et al., 2007; human: Telfer et al., 2008; bovine: Shimizu et al., 2008; ovine: Andrade et al., 2005; goat: Matos et al., 2010; for reviews see Fortune, 2003; Van den 
Hurk \& Zhao, 2005; Picton et al., 2008; Van den Hurk \& Santos, 2009; Smitz et al., 2010).

Follicles are cultured in defined media, like minimal essential medium (MEM; Martins et al., 2010), Waymouth medium (Bolamba et al., 2002) or McCoy medium (Duleba et al., 2001). The type of medium used in in vitro studies has a significant influence on the survival and growth of mammalian follicles. MEM has been used to culture tissues from various species, including bovine (Braw-Tal \& Yossefi, 1997) and caprine (Silva et al., 2004) ovarian tissue as well as murine preantral follicles (Zhao et al., 2001). To prevent follicles from atresia, these media mostly include a protein source (like albumin, fetal calf serum or homogeneous serum), antibiotics, antimycotics, transferring (to bind metal ions) and selenium (to bind free radicals), glutamine, pyruvate (energy sources) and occasionally one or more growth factors (like insulin-like growth factor (IGF)-1, epidermal growth factor (EGF), activin-A, growth differentiation factor9 (GDF-9) and fibroblast growth factor (FGF)-2), hormones (like insulin, follicle stimulating hormone (FSH), growth hormone, thyroid stimulating hormone (TSH) and thyroxine) and/or steroids (like oestradiol, testosterone or androstenedione), sometimes added in a timely manner (for reviews, see Telfer, 1998; Fortune et al., 1999; Van den Hurk et al., 2000; Picton et al., 2003; Smitz et al., 2010). Ascorbic acid is a protective substance that can be added to the culture medium of early-stage follicles. At physiological concentrations, ascorbic acid, or vitamin $\mathrm{C}$, is a potent free radical scavenger, protecting cells against the damage caused by reactive oxygen species (ROS; Carr \& Frei, 1999). The antioxidant properties of ascorbic acid are attributed to its capacity to significantly reduce the damage from ROS, forming ascorbate as a stable free radical (Lutsenko et al., 2002). Ascorbic acid accumulates in granulosa cells, the inner theca, luteal cells, and oocytes (Thomas et al., 2001). In addition, during follicular growth, ovulation, and corpus luteum formation, the basement membrane and extracellular matrix undergo constant remodeling, thus requiring a great deal of collagen, by which ascorbic acid plays a role in the process of collagen synthesis (Li \& Schellhorn, 2007). It was furthermore demonstrated that this antioxidant is able to reduce apoptosis in follicles from cows (Thomas et al., 2001) and rats (Murray et al., 2001), and to maintain follicular survival and to promote the in vitro activation and growth of goat primordial follicles (Rossetto et al., 2009). To our knowledge, there are no reports describing the dose-dependant effects of ascorbic acid on bovine early-stage follicles cultured in vitro.

The objective of the present study of in vitro cultured bovine ovarian tissue fragments was to evaluate the effects of different concentrations of ascorbic acid on the growth and the viability of the ovarian tissue enclosed early-stage follicles.

\section{Materials and methods}

\section{Chemicals}

Unless stated otherwise, the culture media, ascorbic acid, and other chemicals used in this study were purchased from Sigma Chemical Co. (St. Louis, MO, USA).

\section{Source of ovaries}

Ovarian cortical tissues ( $n=10$ ovaries) were collected at a local abattoir from five adult, non-pregnant Nelore cows (Bos indicus). The animals were cyclic and in good body condition. Immediately postmortem, the ovaries were washed in $70 \%$ alcohol for $10 \mathrm{~s}$ followed by two washes with minimum essential medium (MEM) supplemented with $100 \mu \mathrm{g} / \mathrm{ml}$ penicillin and $100 \mu \mathrm{g} / \mathrm{ml}$ streptomycin. The pairs of ovaries were transported in MEM at $20^{\circ} \mathrm{C}$, within $1 \mathrm{~h}$ to the laboratory.

\section{Experimental protocol}

In the laboratory, the ovaries from each animal were stripped of surrounding fat tissue and ligaments and then cut in half. The medulla, large antral follicles and corpora lutea were removed. Subsequently, the ovarian cortex of each pair of ovaries was divided into 25 fragments approximately $3 \times 3 \times 1 \mathrm{~mm}$. The tissue pieces were then either fixed directly for histological, immunohistochemical and ultrastructural analysis (fresh control) or placed in culture for 2, 4, 6 or 8 days.

Bovine tissues were transferred to 24-well culture dishes containing $1 \mathrm{ml}$ of culture medium. The culture was performed at $39^{\circ} \mathrm{C}$ in $5 \% \mathrm{CO}_{2}$ in a humidified incubator, and all the media were incubated for 1 $\mathrm{h}$ prior to use. The basic culture medium (control medium) consisted of MEM ( $\mathrm{pH}$ 7.2-7.4) supplemented with insulin $6.25 \mathrm{ng} / \mathrm{ml}$, transferrin $6.25 \mathrm{ng} / \mathrm{ml}$ and selenium $6.25 \mathrm{ng} / \mathrm{ml}$ (ITS), $0.23 \mathrm{mM}$ pyruvate, $2 \mathrm{mM}$ glutamine, $2 \mathrm{mM}$ hypoxanthine, $1.25 \mathrm{mg} / \mathrm{ml}$ bovine serum albumin (BSA), and antibiotics (200 $\mathrm{UI} / \mathrm{ml}$ penicillin and $200 \mathrm{mg} / \mathrm{ml}$ streptomycin), and this medium was called MEM+. For the experimental conditions, the medium was supplemented with ascorbic acid at five different concentrations $(5,25,50$, 100 or $200 \mu \mathrm{g} / \mathrm{ml}$ ). Ovarian tissue was processed for classical histology, transmission electron microscopy (TEM) and immunohistochemical demonstration of proliferating cell nuclear antigen (PCNA). Each treatment was repeated five times, and the culture medium was replenished every other day. 


\section{Morphological analysis and assessment of granulosa cell proliferation by PCNA}

Either immediately after recovery or after culture for $2,4,6$ or 8 days, pieces of ovarian tissue were fixed by immersion in Bouin's fluid for $12 \mathrm{~h}$, dehydrated in a graded series of ethanol solutions, clarified with xylene and embedded in paraffin wax. Thereafter, 5$\mu \mathrm{m}$ sections of each piece were cut and mounted on glass microscope slides. The majority of these slides was stained with periodic acid Schiff (PAS) and hematoxylin, although every fifth slide was instead stained with antibodies against PCNA (DAKO, Carpinteria, CA, USA), as described previously (Oktay et al., 1995). For PAS staining, the tissue sections were first deparaffinized using xylene and then rehydrated using $70 \%$ ethanol before being stained with periodic acid (Sigma, St. Louis, MO, USA) for $5 \mathrm{~min}$ and Schiff reagent for $10 \mathrm{~min}$. For immunohistochemistry, the sections were similarly deparaffinized and rehydrated but then incubated for $8 \mathrm{~min}$ at $93-98^{\circ} \mathrm{C}$ in citric buffer ( $\mathrm{pH}$ 6). Next, these sections were incubated in $3 \% \mathrm{H}_{2} \mathrm{O}_{2}$ for $30 \mathrm{~min}$ at room temperature $\left(30^{\circ} \mathrm{C}\right)$ to block endogenous peroxidase activity and, after washing, bathed in normal rabbit serum for $20 \mathrm{~min}$ at room temperature to inhibit non-specific binding. Immunostaining per se was performed by incubation in a 1:100 dilution of the primary antibody (antiPCNA, Zymed) for $18 \mathrm{~h}$ at $8^{\circ} \mathrm{C}$ followed by washing and incubation in a rabbit anti-mouse second IgG (DAKO, Carpinteria, CA, USA) at a 1:200 dilution for $30 \mathrm{~min}$. For control sections, the primary antibody was replaced by Tris-buffered saline. Finally, streptavidinbiotin complex was added for $30 \mathrm{~min}$ at room temperature, followed by diaminobenzidine (DAB) for a further $7 \mathrm{~min}$. After completion of the reactions, the sections were counterstained with hematoxylin. Approximately 150 follicles were randomly evaluated in each medium and culture period.

The developmental stages of the follicles have been defined previously (Silva et al., 2004) as primordial (one layer of flattened granulosa cells around the oocyte) or growing (intermediate, one layer of flattened to cuboidal granulosa cells; primary, one layer of cuboidal granulosa cells; and secondary, two or more layers of cuboidal granulosa cells around the oocyte). Each follicle was evaluated according to the following morphological parameters: (1) integrity of oocyte and granulosa cells; (2) presence or absence of pyknotic bodies; (3) ooplasmic retraction; (4) organisation of granulosa cells; and (5) presence of a non-undulated basement membrane, firmly attached to the granulosa cells. Based on this evaluation, preantral follicles were classified as normal, when a morphologically normal oocyte with a non-pyknotic nucleus was surrounded by granulosa cells organized in discrete layers. Degenerated follicles were defined as those with a retracted oocyte, with a pyknotic nucleus and/or surrounded by disorganized granulosa cells, which were detached from the basement membrane. An average of 150 follicles were evaluated for each treatment (ca. 30 follicles per treatment in one repetition $\times$ five repetitions $=$ ca. 150 follicles).

To evaluate follicular activation and growth, only intact follicles with a visible oocyte nucleus were recorded and the proportion of primordial and growing follicles were calculated at day 0 (control) and after 2, 4, 6 or 8 days of culture in the various media tested. Care was taken to count each follicle only once; each follicle was examined in every section in which it appeared and matched with the same follicle on adjacent sections to avoid double counting, thus ensuring that each follicle was counted only once, regardless of its size.

\section{Ultrastructural analysis}

Small pieces $\left(1 \mathrm{~mm}^{3}\right.$-from the same fragments used in other analysis) of bovine ovarian tissue were fixed in $2 \%$ paraformaldehyde and $2.5 \%$ glutaraldehyde in 0.1 $\mathrm{M}$ sodium cacodylate buffer ( $\mathrm{pH}$ 7.2) for $4 \mathrm{~h}$ at room temperature. After fixation, fragments were post-fixed in $1 \%$ osmium tetroxide, $0.8 \%$ potassium ferricyanide, and $5 \mathrm{mM}$ calcium chloride in $0.1 \mathrm{M}$ sodium cacodylate buffer for $1 \mathrm{~h}$. Subsequently, the samples were dehydrated through a gradient of acetone solutions and the tissues were embedded in Spurr. Semi-thin sections $(3 \mu \mathrm{m})$ were cut on an ultramicrotome (Reichert Supernova, Heidelberg, Germany) and stained with toluidine blue for light microscopy studies. The ultrathin sections $(60-70 \mathrm{~nm})$ were contrasted with uranyl acetate and lead citrate, and examined under a Jeol 1011 (Jeol, Tokyo, Japan) transmission electron microscope. Parameters such as the density and integrity of ooplasmic and granulosa cell organelles, vacuolization, and basement membrane integrity were evaluated.

\section{Statistical analysis}

Pair-wise comparisons were done using Tukey's procedure. Chi-squared test was used to compare percentages of follicles with PCNA-positive granulosa cells. All analyses were performed with the Statistical Analysis System (SAS Institute, Cary, NC, USA) and values were considered statistically significant when $p<0.05$.

\section{Results}

\section{Bovine early-stage follicle survival and activation during in-vitro culture}

In total, 3750 early-stage follicles were analyzed: 2013 primordial, 1275 intermediate, 398 primary and 


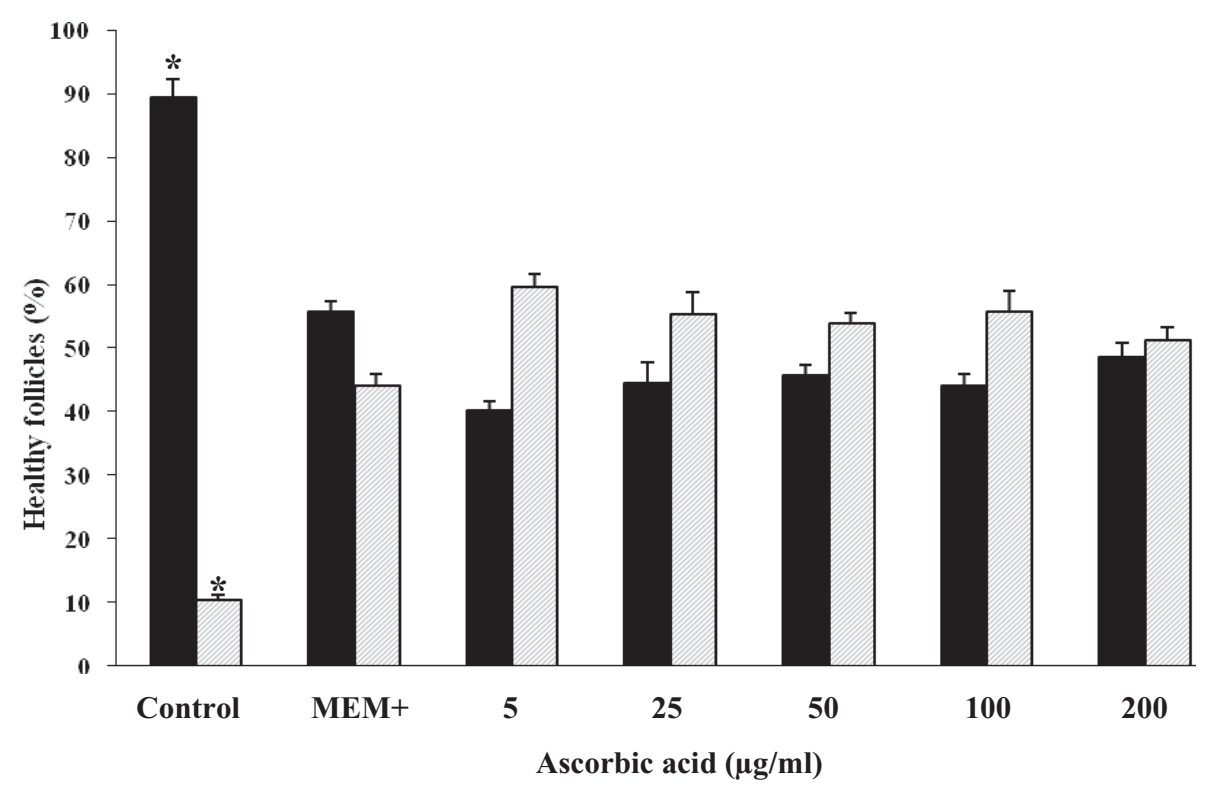

Figure 1 Mean \pm standard error of the mean (SEM) percentages of healthy early-stage bovine follicles that were at primordial (ם) and developing (i) stages in non-cultured ovarian tissue (control) and in ovarian tissue after in vitro culture for 8 days in minimum essential medium (MEM+) or in MEM+ supplemented with different concentrations $(\mu \mathrm{g} / \mathrm{ml})$ of ascorbic acid. For both primordial-stage and developing-stage follicles, there were differences $(p<0.05$ for each) in percentages of healthy follicles between the control group and all cultured groups, but no significant differences in this regard among the cultured groups. *Different $(p<0.05)$ from other treatments.

64 secondary follicles. Histological analysis showed that normal and degenerated follicles were found in fragments of ovarian cortex before and after in vitro culture. In degenerated follicles, the main characteristics observed were a retracted oocyte, a pyknotic nucleus and disorganized granulosa cells, with low cellular density.

Non-cultured ovarian tissue fragments (day 0) largely contained primordial follicles (89.6\%) near to a small percentage of developing follicles $(10.4 \%)$ (Fig. 1). These percentages had significantly $(p<0.05)$ decreased and increased, respectively, when ovarian tissues were cultured for 8 days in MEM+ or MEM+ supplemented with five different concentrations of ascorbic acid. Among the ovarian tissues that have been cultured in MEM+ and MEM+ supplemented with five different concentrations of ascorbic acid no significant differences in percentages of primordial follicles nor in those of developing follicles were observed.

Data for follicular viability are shown in Fig. 2. The percentage of viable follicles was significantly lower $(p<0.05)$ than that $(93.7 \%)$ of the control group in ovarian tissues that have been cultured in MEM+ for 4, 6 and 8 days and MEM+ supplemented with 5 or $200 \mu \mathrm{g} / \mathrm{ml}$ of ascorbic acid for 6 or 8 days. The other ascorbic acid treatments did not result in viability percentages that were significantly different from that of follicles from the control group. Regarding the effect

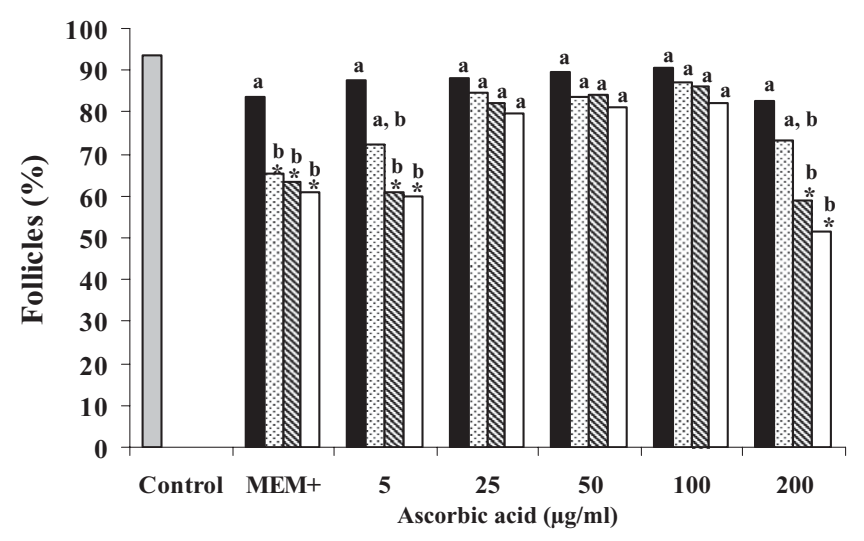

Figure 2 Mean \pm standard error of the mean (SEM) percentages of early-stage bovine follicles that were healthy (viable) in non-cultured ovarian tissue (control) and in tissue after culture for 2 days (ם) 4 days ( ), 6 days (售) or 8 days ( $\square$ ) in MEM+ or MEM+ supplemented with different concentrations of ascorbic acid $(\mu \mathrm{g} / \mathrm{ml})$.

*Significant different $(p<0.05)$ from the Control group.

${ }^{a, b}$ Within treatments, adjacent bars without a common superscript differ $(p<0.05)$.

of the duration of performed cultures, the percentage of healthy follicles had decreased significantly $(p<$ 0.05 ) from culture day 4 onwards in MEM+, and from culture day 6 onwards in MEM+ supplemented with 5 or $200 \mu \mathrm{g} / \mathrm{ml}$ of ascorbic acid. 


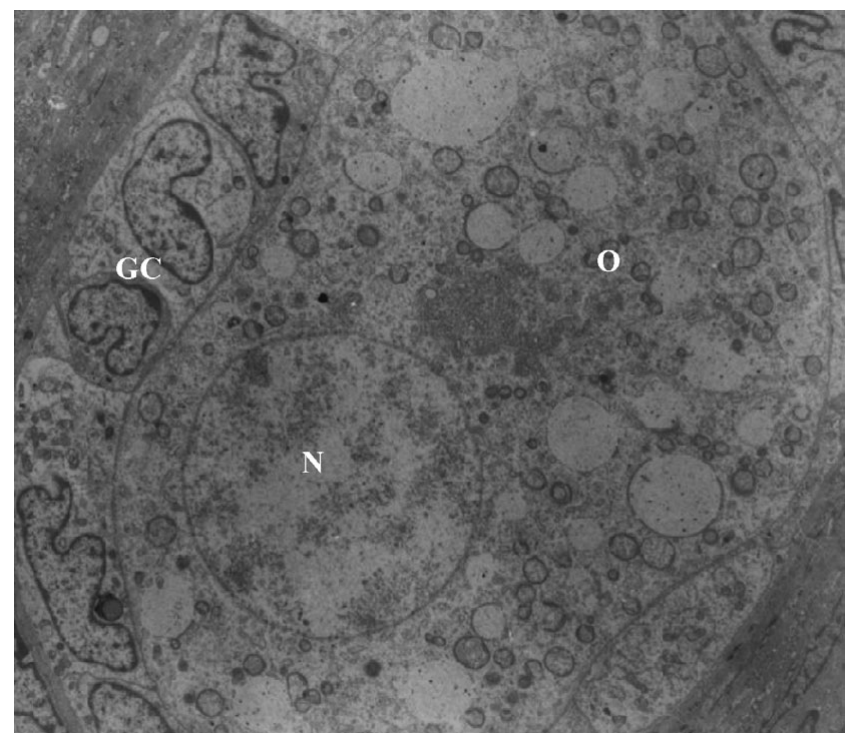

Figure 3 Electron micrography of a normal bovine preantral follicle (control) showing an oocyte $(\mathrm{O})$ with intact nucleus $(\mathrm{N})$, surrounded by an organized layer of granulosa cells (GC).

\section{Ultrastructural analysis of bovine early-stage follicles}

For a better evaluation of follicular integrity, ultrastructural analysis was performed with tissues from fresh control as well as with tissues that had been cultured for 8 days in MEM+ containing 25, 50 or $100 \mu \mathrm{g} / \mathrm{ml}$ of ascorbic acid, all of which showing satisfactory results at histological evaluation with regard to follicular health, growth, and activation. Ultrastructural features of follicles evaluated in fresh control (Fig. 3) or in those cultured for 8 days with $50 \mu \mathrm{g} / \mathrm{ml}$ of ascorbic acid were similar and showed intact oocyte and nuclear membranes and large oocyte nuclei (Fig. 4). Organelles were uniformly distributed in the ooplasm, especially in mitochondria and the endoplasmic reticulum. The homogeneous cytoplasm furthermore contained numerous rounded mitochondria with peripheral cristae and continuous mitochondrial membranes, although there were occasional elongated forms with parallel cristae. The oocyte nucleus had uncondensed chromatin and the nucleolus could generally be observed. In addition, granulosa cells were ultrastructurally normal, showing an elongated and large nucleus with an irregular membrane and a high proportion of nucleus to cytoplasm. The nuclei were irregularly shaped, with loose chromatin in the inner part and small peripheral aggregates of condensed chromatin. In contrast, follicles cultured with 25 or $100 \mu \mathrm{g} / \mathrm{ml}$ of ascorbic acid (Fig. 5) showed signs of degeneration. Such follicles showed an oocyte extremely vacuolated, with vacuoles

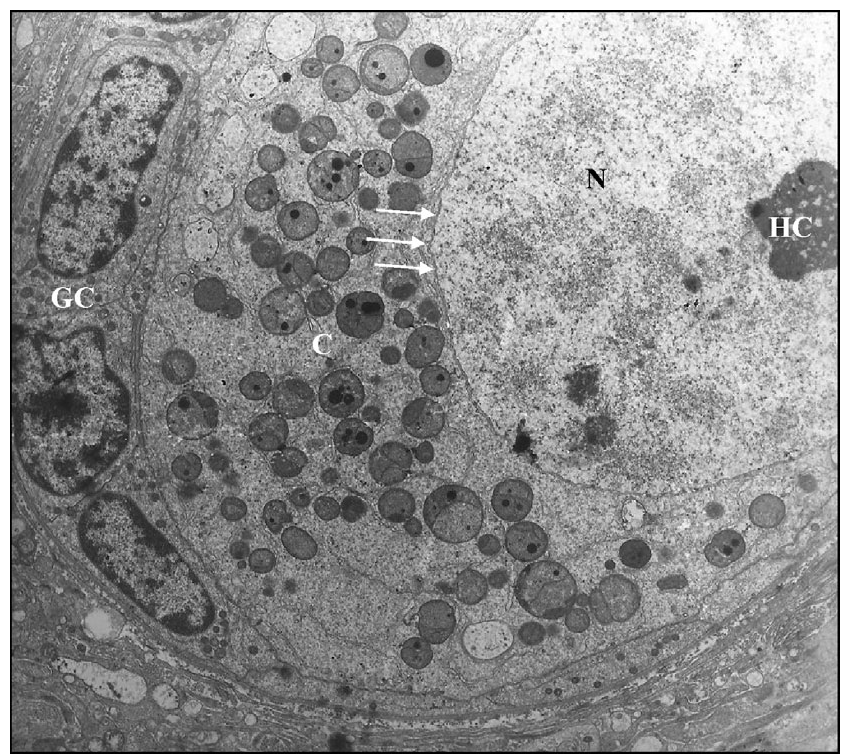

Figure 4 Electron micrography of a normal bovine preantral follicle cultured for 8 days with $50 \mu \mathrm{g} / \mathrm{ml}$ of ascorbic acid. Note the presence of an intact nuclear envelope (arrows) between nucleus $(\mathrm{N})$ and cytoplasm $(\mathrm{C})$ and heterochromatin (HC) in the nucleus. GC: granulosa cells.

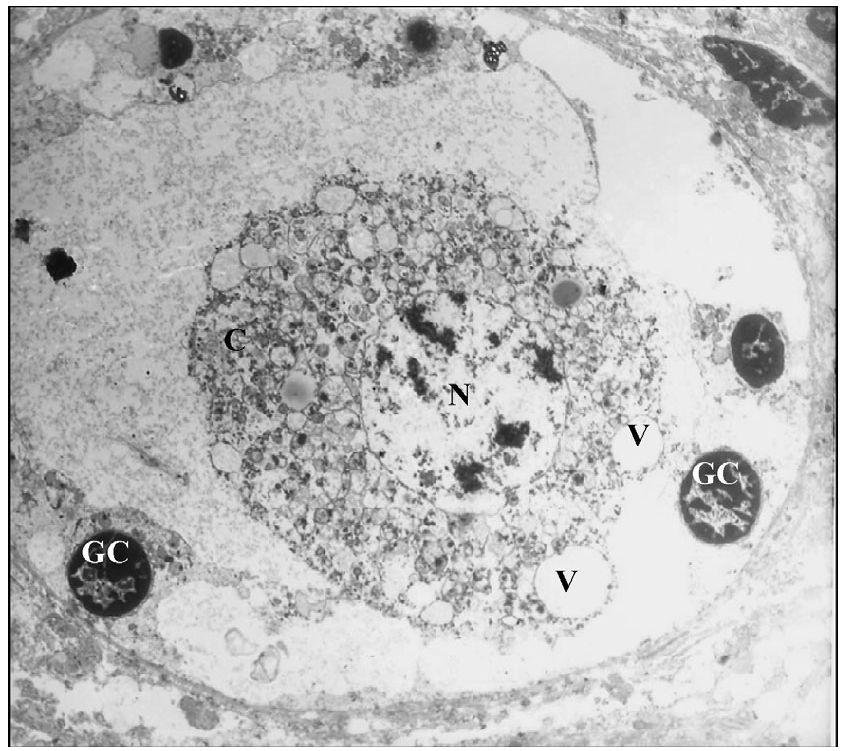

Figure 5 Electron micrography of a degenerated bovine preantral follicle cultured for 8 days with $100 \mu \mathrm{g} / \mathrm{ml}$ of ascorbic acid. Note the presence of large vacuoles (V) in the oocyte cytoplasm (C) and the swollen granulosa cells (GC). $\mathrm{N}$ : nucleus.

often being fused thus producing a large vacuolated area. Organelles were more randomly distributed throughout the cytoplasm and signs of endoplasmic reticulum proliferation and damage to mitochondrial membranes and cristae were observed. The oocyte nucleus appeared misshapen and retracted and had 
Table 1 Percentages of primordial and developing follicles with proliferating cell nuclear antigen (PCNA)-positive granulosa cells in non-cultured ovarian tissue and tissue cultured for 8 days in minimal essential medium (MEM+) (control) and MEM+ supplemented with 25, 50 or $100 \mu \mathrm{g} / \mathrm{ml}$ of ascorbic acid.

\begin{tabular}{|c|c|c|}
\hline Culture & $\begin{array}{c}\text { Primordial follicles with PCNA-positive } \\
\text { granulosa cells (\%) }\end{array}$ & $\begin{array}{l}\text { Developing follicles with PCNA- } \\
\text { positive granulosa cells (\%) }\end{array}$ \\
\hline Non-cultured & 5.7 & 38.4 \\
\hline $\mathrm{MEM}+{ }^{a}$ & 5.3 & 36.9 \\
\hline MEM+ $25 \mu \mathrm{g} / \mathrm{ml}$ ascorbic acid $^{a}$ & 7.1 & 42.0 \\
\hline $\mathrm{MEM}+50 \mu \mathrm{g} / \mathrm{ml}$ ascorbic acid $^{a}$ & $18.3^{b}$ & $63.4^{b}$ \\
\hline $\mathrm{MEM}+100 \mu \mathrm{g} / \mathrm{ml}$ ascorbic acid $^{a}$ & 6.7 & 44.7 \\
\hline
\end{tabular}

${ }^{a}$ In vitro culture for 8 days.

${ }^{b}$ Significant different $(p<0.05)$.
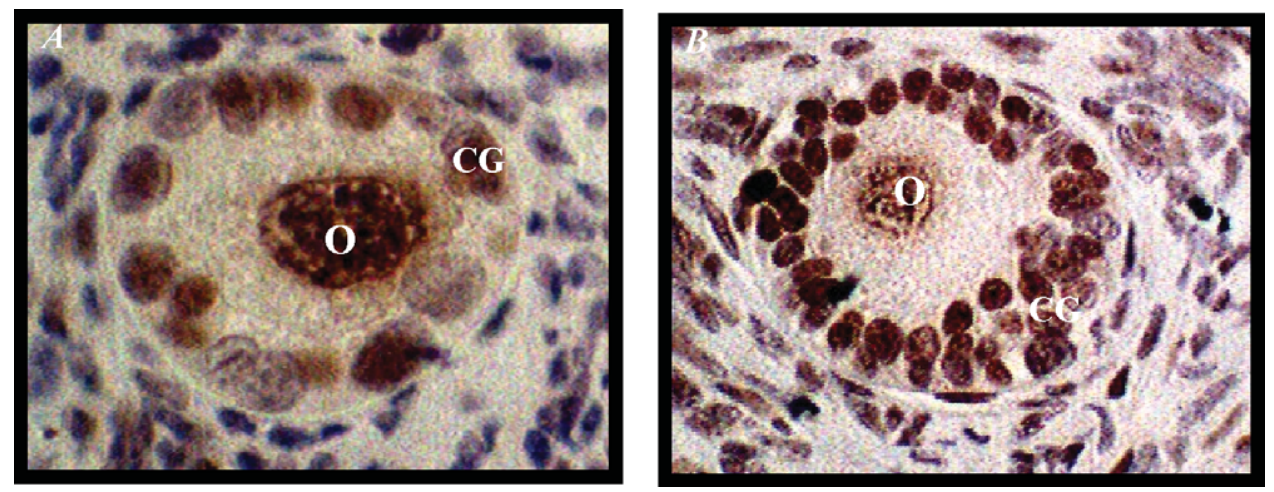

Figure 6 Sections of bovine ovarian tissue after in vitro culture, showing $(A)$ a primary and $(B)$ a secondary follicle with granulosa cell nuclei that stain brown, i.e. positive for PCNA. O: oocyte nucleus; GC: granulosa cells.

a wavy membrane. Granulosa cells look swollen, while the density of cytoplasmic organelles was low. Frequently, the connection between the oocyte and their surrounding granulosa cells had disappeared, while organelles were no longer identifiable.

\section{Evaluation of bovine granulosa cell proliferation using PCNA}

Only intact follicles were used for PCNA evaluation (Fig. 6). In general, marked primordial follicles had only one PCNA-positive granulosa cell, while intermediate and primary follicles showed one to four positive granulosa cells. Secondary follicles presented a higher number of PCNA-labelled granulosa cells (up to 15 cells). In non-cultured bovine ovarian cortex only $5.7 \%$ of the primordial follicles had a PCNA-positive granulosa cell, while $38.4 \%$ of the developing follicles (i.e. intermediate, primary and secondary follicles) showed at least one PCNA-positive granulosa cell (Table 1). Only the percentages of primordial and developing follicles with stained granulosa cells after in vitro culture with $50 \mu \mathrm{g} / \mathrm{ml}$ of ascorbic acid were significantly higher than those in non-cultured ovarian tissue and in tissue cultured in presence of 25 or $100 \mu \mathrm{g} / \mathrm{ml}$ ascorbic acid $(p<0.05)$; the tissues from the last two treatments showed comparable percentages of
PCNA-positive granulosa cells as found in those of the control group $(p<0.05)$.

\section{Discussion}

This study has demonstrated a positive effect of ascorbic acid on the survival, activation and growth of bovine early-stage follicles during 8 days of in vitro culture.

In vivo, the transition of primordial to primary follicles and subsequent development to the secondary stage is characterized by a slow transformation of granulosa cells from a flattened to a cuboidal shape and a subsequent slow proliferation of these cells over approximately 25 (sheep: McNatty et al., 1995), 30 (cow: Braw-Tal \& Yossefi, 1997) or 120 (woman: Gougeon, 1996) days. The non-growing population of primordial follicles is located in a thin, relatively avascular layer outermost in the ovarian cortex, just beneath the tunica albuginea, whereas the growing follicles are always found at the richly vascularized cortico-medullary border. This situation suggests that activation and growth of primordial follicles depends on blood-borne nutrients, hormones, and/or growth factors (McNatty et al., 2000). Culture in vitro appears to induce 
activation of primordial follicles, probably because the media are richer in nutrients, oxygen, insulin, etc than the outermost ovarian cortex. Such environmental changes may stimulate follicle development either directly, or indirectly via the release of stimulatory factors or cessation of production of inhibitory factors by stromal, granulosa or pre-thecal cells within the cultured ovarian cortical tissue.

In the present study, tested media did not seem to be equally effective in maintaining the survival and development of bovine early-stage follicles. Based on histological results, after 8 days of in vitro culture, MEM+ supplemented with 25, 50 or $100 \mu \mathrm{g} / \mathrm{ml}$ of ascorbic acid showed better results than the medium supplemented with MEM+ only or MEM+ supplemented with 5 or $200 \mu \mathrm{g} / \mathrm{ml}$ of ascorbic acid. In correspondence with our results, Thomas et al. (2001) previously demonstrated the maintenance of follicular integrity and survival after in vitro culture of isolated bovine early-stage follicles for 12 days in medium containing $50 \mu \mathrm{g} / \mathrm{ml}$ of ascorbic acid. The in vitro culture results in higher oxygen concentrations than in vivo environments, leading to an increased level of reactive oxygen species (ROS; Luvoni et al., 1996). Polyunsaturated lipids of cellular membranes are very sensitive to peroxidation by ROS. At physiological concentrations, ascorbic acid is an antioxidant that protects cells against the damage caused by ROS (Carr and Frei, 1999). Among the actions of ascorbic acid are the prevention of DNA mutations induced by oxidation (Lutsenko et al., 2002; Sweetman et al., 1997) and protection against lipidic peroxidation (Barja et al., 1994; Kimura et al., 1992). Ascorbic acid accumulates in the granulosa cells, inner theca, luteal cells, and oocytes (Thomas et al., 2001). Murray et al. (2001) observed that, at a concentration of $50 \mu \mathrm{g} / \mathrm{ml}$, ascorbic acid promoted an increase in basement membrane remodelling and granulosa cell survival in isolated mouse late secondary follicles cultured in vitro for 6 days. During follicular growth, ovulation and corpus luteum formation, the basement membrane and extracellular matrix undergo constant remodelling and therefore need a large amount of collagen. In this way, ascorbic acid acts intensively in follicular growth through its action in the biosynthesis of collagen, which influences the process of cellular membrane remodeling (Li \& Schellhorn, 2007).

After 8 days of culture, the use of MEM+ only, 5 or $200 \mu \mathrm{g} / \mathrm{ml}$ of ascorbic acid reduced the percentage of normal early-stage follicles in comparison to that present in the ovarian cortical tissue of the control group. When using concentrations of 25, 50 or $100 \mu \mathrm{g} / \mathrm{ml}$, the percentage of normal follicles remained similar to that of the control group. The knowledge that some antioxidant substances act as pro-oxidants when used in high concentrations
(Andrade et al., 2010), could explain that ascorbic acid at concentrations higher than $100 \mu \mathrm{g} / \mathrm{ml}$ is toxic to cattle early-stage follicles cultured in vitro. Furthermore, high concentrations of ascorbic acid can inhibit important physiological processes in the ovary, resulting in follicular degeneration (Murray et al., 2001). Moreover, high concentrations of ascorbic acid may promote oxidative damage to cellular DNA, especially in the presence of $\mathrm{Cu}^{2+}$ and $\mathrm{Fe}^{2+}$ ions, which react with hydrogen peroxide and lead to the formation of the highly reactive hydroxyl radicals that cause damage ( $\mathrm{Li} \&$ Schellhorn, 2007). Olson and Seidel (2000) reported that co-supplementation of ascorbic acid at a concentration of $100 \mathrm{mM}$ each had a deleterious effect on the embryo culture medium. The balance between antioxidants and pro-oxidants must be preserved in the cells. An excess of antioxidant compounds can increase the redox state, which may have deleterious effects on embryos (Guérin et al., 2001). In the present study, the ascorbic acid free medium (MEM+) and the medium supplemented with the lowest $(5 \mu \mathrm{g} / \mathrm{ml})$ or highest $(200 \mu \mathrm{g} / \mathrm{ml})$ dose of ascorbic acid were not effective in maintaining follicular viability during in vitro culture.

Several authors have emphasized the importance of TEM after in vitro culture of early-stage follicles, as it gives close insight into the ultrastructural characteristics of follicles, allowing a better evaluation of their quality (Van den Hurk et al., 1998; Zhao et al., 2000; Salehnia et al., 2002). In the present study, bovine earlystage follicles that have been cultured for 8 days in MEM+ supplemented with $50 \mu \mathrm{g} / \mathrm{ml}$ of ascorbic acid appeared ultrastructurally normal, which confirmed the results obtained in the histological studies from this test group. In contrast, most follicles from ovarian tissues cultured in presence of 25 or $100 \mu \mathrm{g} / \mathrm{ml}$ ascorbic acid, i.e. groups that also largely consist of histologically normal follicles, showed various ultrastructural signs of initial degeneration after 8 days of culture and besides exhibited more obvious degenerative features, like ooplasm vacuolization. Cytoplasmic vacuoles are characteristic signs of degeneration in oocytes (Silva et al., 2000), granulosa (Hay et al., 1976) and cumulus cells (Assey et al., 1994) and may represent endoplasmic reticulum swelling (Tassel \& Kennedy, 1980) or altered mitochondrial structure (Fuku et al., 1995). Therefore, we conclude from our histological and ultrastructural findings that ascorbic acid exerts its optimal effect on bovine follicular integrity and survival, when added to culture media in a concentration of $50 \mu \mathrm{g} / \mathrm{ml}$. This concentration is exactly the dose used in the studies of Thomas and co-workers (2001) with isolated bovine follicles, who based their choice for the ascorbic acid concentration on results from experiments with mouse late secondary follicles (Murray et al., (2001). 
The PCNA staining of granulosa cells was indicative of their proliferation. PCNA staining in oocytes may be due to DNA repair (Downey et al., 1990) during the intense RNA transcription that occurs in growing oocytes (Lintern-Moore \& Moore, 1979). In agreement with our findings, the onset of bovine primordial follicle growth was also accompanied by PCNA expression in granulosa cells and oocytes (Wandji et al., 1996), which shows that mitotic activity of granulosa cells is initiated as soon as the primordial follicles leave the resting pool and start to grow. In the current study, the proportion of follicles stained with PCNA had significantly increased after 8 days of culture, but only when ascorbic acid was added to the culture medium in a concentration of $50 \mu \mathrm{g} / \mathrm{ml}$. Thus, only at this particular concentration ascorbic acid appears able to stimulate the proliferation of granulosa cells. Such an increased proliferation of granulosa cells, in in vitro cultured developing bovine follicles corresponds with that observed in previous in vivo studies with other mammals (humans: Oktay et al., 2000; rats: Oktay et al., 1995; goats: Silva et al., 2004) and indicates that the in vitro cultured follicles grow through proliferation of granulosa cells. In contrast to growing follicles, primordial follicles show a low percentage of PCNA expression in granulosa cells. Similar results were described in rats (Meredith et al., 2000) and monkeys (Gougeon \& Busso, 2000), while mitotic activity had increased when granulosa cells become cuboidal. Cellcell interactions among oocyte, granulosa and stromal cells have been shown to be essential for the activation of primordial follicles (reviewed by McGee \& Hsueh (2000); Picton (2001); and Eppig (2001)).

In summary, dose dependently, ascorbic acid has an important role in bovine early folliculogenesis in vitro. At a concentration of $50 \mu \mathrm{g} / \mathrm{ml}$, ascorbic acid realizes optimal early-stage follicle survival, based on histological and ultrastructural features, and promotes the activation of primordial follicles and further follicle growth.

\section{Financial support}

E.R. Andrade and A.A. Alfieri are recipients of a PRODOC/CAPES fellowship.

\section{References}

Andrade, E.R., Seneda, M.M., Alfieri, A.A., de Oliveira, J.A, Bracarense, A.P.F.R.L., Figueiredo, J.R. \& Toniolli, R. (2005). Interactions of indole acetic acid with EGF and FSH in the culture of ovine preantral follicles. Theriogenology 64, 110413.

Andrade, E.R., Melo-Sterza, F.A., Seneda, M.M. \& Alfieri, A.A. (2010). Consequências da produção das espécies reativas de oxigênio na reprodução e principais mecanismos antioxidantes. Rev. Bras. Reprod. Anim. 34, 79-85.

Assey, R.J., Hyttel, P., Roche, J.F. \& Boland, M.P. (1994). Infrequent structures in cattle oocytes. Anat. Embryol. 190, 263-71.

Barja, G., Lopez-Torres, M., Perez-Campo, R., Rojas, C., Cadenas, S., Prat, J. \& Pamplona, R. (1994). Dietary vitamin $\mathrm{C}$ decreases endogenous protein oxidative damage, malondialdehyde, and lipid peroxidation and maintains fatty acid unsaturation in the guinea pig liver. Free Radic. Biol. Med. 17, 105-15.

Bolamba, D., Floyd, A.A., McGlone, J.J. \& Lee, V.H. (2002). Epidermal growth factor enhances expression of connexin 43 protein in cultured porcine preantral follicles. Biol. Reprod. 67, 154-160.

Braw-Tal, R. \& Yossefi, S. (1997). Studies in vivo and in vitro on the initiation of follicle growth in the bovine ovary. J. Reprod. Fertil. 109, 165-71.

Carr, A. \& Frei, B. (1999). Does vitamin C act as a pro-oxidant under physiological conditions? FASEB J. 13, 1007-24.

Downey, K.M., Tan, C.K. \& So, A.G. (1990). DNA polymerase delta: a second eucaryotic DNA replicase. Bioessays 12, 231-36.

Duleba, A.J., Pehlivan, T., Carbone, R. \& Spaczynski, R.Z. (2001). Activin stimulates proliferation of rat ovarian thecal-interstitial cells. Biol Reprod 65, 704-709.

Eppig, J.J. (2001). Oocyte control of ovarian follicular development and function in mammals. Reproduction 122, 829-38.

Fortune, J.E., Kito, S. \& Byrd, D.D. (1999). Activation of primordial follicles in vitro. J. Reprod. Fert. Suppl. 54, 43948.

Fortune, J.E. (2003). The early stages of follicular development: activation of primordial follicles and growth of preantral follicles. Anim. Reprod. Sci. 78, 135-63.

Fuku, E., Xia, L. \& Downey, B.R. (1995). Ultrastructural changes in bovine oocytes cryopreserved by vitrification. Cryobiology 32, 139-56.

Gao, M.Z., Wang, Y. \& WU, X. (2007). In vitro maturation of immature oocytes from preantral follicles in prepuberal mice. J. Reprod. Contracept. 18, 25-32.

Gougeon, A. (1996). Regulation of ovarian follicular development in primates: facts and hypotheses. Endocr. Rev. 17, 121-54.

Gougeon, A. \& Busso, D. (2000). Morphologic and functional determinants of primordial and primary follicles in the monkey ovary. Mol. Cell. Endocrinol. 163, 33-41.

Guérin, P., El Mouatassim, S. \& Ménézo, Y. (2001). Oxidative stress and protection against reactive oxygen species in the pre-implantation embryo and its surroundings. Hum. Reprod. Update 7, 175-89.

Hay, M.F., Cran, D.G. \& Moor, R.M. (1976). Structural changes occuring during atresia in sheep ovarian follicles. Cell Tissue Res. 169, 515-29.

Kimura, H., Yamada, Y., Morita, Y., Ikeda, H. \& Matsuo, T. (1992). Dietary ascorbic acid depresses plasma and low density lipoprotein lipid peroxidation in genetically scorbutic rats. J. Nutr. 122, 1904-9.

Li, Y. \& Schellhorn, H.E. (2007). New developments and novel therapeutic perspectives for vitamin C. J. Nutr. 137, 2171-84. 
Lintern-Moore, S. \& Moore, G.P.M. (1979). The initiation of follicle and oocyte growth in the mouse ovary. Biol. Reprod. 20, 773-78.

Lutsenko, E.A., Carcamo, J.M. \& Golde, D.W. (2002). Vitamin C prevents DNA mutation induced by oxidative stress. J. Biol. Chem. 277, 16895-9.

Luvoni, G.C., Keskintepe, L. \& Brackett, B.G. (1996). Improvement in bovine embryo production in vitro by glutathione-containing culture media. Mol. Reprod. Dev. 43, 437-43.

Martins, F.S., Celestino, J.J.H., Saraiva, M.V.A., Chaves, R.N., Rossetto, R., Silva, C.M.G., Lima-Verde, I.B., Lopes, C.A.P., Campello, C.C. \& Figueiredo, J.R. (2010). Interaction between growth differentiation factor 9, insulin-like growth factor I and growth hormone on the in vitro development and survival of goat preantral follicles. Braz. J. Med. Biol. Res. 43, 728-736.

Matos, M.H.T., Bruno, J.B., Rocha, R.M.P., Lima-Verde, I.B., Santos, K.D.B., Saraiva, M.V.A., Silva, J.R.V., Martins, F.S., Chaves, R.N., Báo, S.N. \& Figueiredo, J.R. (2011). In vitro development of primordial follicles after long-term culture of goat ovarian tissue. Res. Vet. Sci. 90, 404-11.

McGee, E.A. \& Hsueh, A.A. (2000). Initial and cyclic recruitment of ovarian follicles. Endocr. Rev. 21, 200-14.

McNatty, K.P., Fidler, A.E., Juengel, J.L., Quirke, L.D., Smith, P.R., Heath, D.A., Lundy, T., O'Connell, A. \& Tisdall, D.J. (2000). Growth and paracrine factors regulating follicular formation and cellular function. Mol. Cell. Endocrinol. 163, 11-20.

McNatty, K.P., Smith, P., Hudson, N.L., Heath, D.A., Tisdall, D.J. \& Braw-Tal, R. (1995). Development of the sheep ovary during fetal and early neonatal life and the effect of fecundity genes. J. Reprod. Fert. Suppl. 49, 123-35.

Meredith, S., Dudenhoeffer, G. \& Jackson, K. (2000). Classification of small type B/C follicles as primordial follicles in mature rats. J. Reprod. Fertil. 119, 43-8.

Murray, A.A., Molinek, M.D., Baker, S.J., Kojima, F.N., Smith, M.F., Hillier, S.G. \& Spears, N. (2001). Role of ascorbic acid in promoting follicle integrity and survival in intact mouse ovarian follicles in vitro. Reproduction 121, 89-96.

Oktay, K., Schenken, R.S. \& Nelson, J.F. (1995). Proliferating cell nuclear antigen marks the initiation of follicular growth in the rat. Biol. Reprod. 53, 295-301.

Oktay, K., Karlikaya, G., Akman, O., Ojakian, G.K. \& Oktay, M. (2000). Interaction of extracellular matrix and Activin A in the initiation of follicle growth in the mouse ovary. Biol. Reprod. 63, 457-61.

Olson, S.E. \& Seidel Jr, G.E. (2000). Culture of in vitroproduced bovine embryos with vitamin $\mathrm{E}$ improves development in vitro and after transfer to recipients. Biol. Reprod. 62, 248-52.

Picton, H.M. (2001). Activation of follicle development: the primordial follicle. Theriogenology 55, 1193-210.

Picton, H.M., Danfour, M., Harris, S.E., Chambers, E \& Huntriss, J. (2003). In vitro growth and maturation of oocyte. Reproduction 61, 445-62.

Picton, H.M, Harris, S.E., Muruvi, W. \& Chambers, E.L. (2008). The in vitro growth and maturation of follicles. Reproduction 136, 703-15.

Rossetto, R., Lima-Verde, I.B., Matos, M.H.T., Saraiva, M.V.A., Martins, F.S., Faustino, L.R., Araújo, V.R., Silva,
C.M.G., Báo, S.N., Campello, C.C., Figueiredo, J.R. \& Blume, H. (2009). Interaction between ascorbic acid and follicle-stimulating hormone maintains follicular viability after long-term in vitro culture of caprine preantral follicles. Domest. Anim. Endocrinol. 37, 112-23.

Salehnia, M., Moghadam, E.A. \& Velojerdi, M.R. (2002). Ultrastructure of follicles after vitrification of mouse ovarian tissue. Fertil. Steril. 78, 644-45.

Shimizu, T., Murayama, C., Sudo, N., Kawashima, C., Tetsuka, M. \& Miyamoto, A. (2008). Involvement of insulin and growth hormone $(\mathrm{GH})$ during follicular development in the bovine ovary. Anim. Reprod. Sci. 106, 143-52.

Silva, J.R.V., Lucci, C.M., Carvalho, F.C.A., Báo, S.N., Costa, S.H.F., Santos, R.R. \& Figueiredo, J.R. (2000). Effect of coconut water and Braun-Collins solutions at different temperatures and incubation times on the morphology of goat preantral follicles preserved in situ. Theriogenology 54, 809-22.

Silva, J.R.V., van den Hurk, R., Costa, S.H.F., Andrade, E.R., Nunes, A.P.A., Ferreira, F.V.A., Lôbo, R.N.B. \& Figueiredo, J.R. (2004). Survival and growth of goat primordial follicles after in vitro culture of ovarian cortical slices in media containing coconut water. Anim. Reprod. Sci. 81, 27386.

Smitz, J., Dolmans, M.M., Donnez, J., Fortune, J.E., Hovatta, O., Jewgenow, K., Picton, H.M., Plancha, C., Shea, L.D., Stouffer, R.L., Telfer, E.E., Woodruff, T.K. \& Zelinski, M.B. (2010). Current achievements and future research directions in ovarian tissue culture, in vitro follicle development and transplantation: implications for fertility preservation. Hum. Reprod. Update 16, 395-414.

Sweetman, S.F., Strain, J.J. \& McKelvey-Martin, V.J. (1997). Effect of antioxidant vitamin supplementation on DNA damage and repair in human lymphoblastoid cells. Nutr. Cancer 27, 122-30.

Tassel, R. \& Kennedy, J.P. (1980). Early follicular development and atretic changes in the ovary of the lamb - fine structure and histochemistry. Aust. J. Biol. Sci. 33, 675-87.

Telfer, E.E. (1998). In vitro Models for Oocyte Development. Theriogenology 49, 451-60.

Telfer, E.E., McLaughlin, M., Ding, C. \& Thong, K.J. (2008). A two-step serum-free culture system supports development of human oocytes from primordial follicles in the presence of activin. Hum. Reprod. 23, 1151-58.

Thomas, F.H., Leask, R., Srsen, V., Riley, S.C., Spears, N. \& Telfer, E.E. (2001). Effect of ascorbic acid on health and morphology of bovine preantral follicles during long-term culture. Reproduction 122, 487-95.

van den Hurk, R., Spek, E.R., Hage, W.J., Fair, T., Ralph, J.H. \& Schotanus, K. (1998). Ultrastructure and viability of isolated bovine preantral follicles. Hum. Reprod. 4, 833-41.

van den Hurk, R., Abir, R., Telfer, E.E. \& Bevers, M.M. (2000). Primate and bovine immature oocytes and follicles as sources of fertilizable oocytes. Hum. Reprod. Update 6, 457-74.

van den Hurk, R. \& Zhao, J. (2005). Formation of mammalian oocytes and their growth, differentiation and maturation within ovarian follicles. Theriogenology 63, 1717-51.

van den Hurk, R. \& Santos, R.R. (2009). Development of fresh and cryopreserved early-stage ovarian follicles, with special attention to ruminants. Anim. Reprod. 6, 72-95. 
Wandji, S.A., Eppig, J.J. \& Fortune, J.E. (1996). FSH and growth factors affect the growth and endocrine function in vitro of granulosa cells of bovine preantral follicles. Theriogenology 45, 817-32.

Zhao, J., Dorland, M., Taverne, M.A., van der Weijden, G.C., Bevers, M.M. \& van den Hurk, R. (2000). In vitro culture of rat pre-antral follicles with emphasis on follicular interactions. Mol. Reprod. Dev. 55, 65-74.

Zhao, J., Tavene, M.A.M., van der Weijden, G.C., Bevers, M.M. \& van den Hurk, R. (2001). Insulin-like growth factor-I (IGF-I) stimulates the development of cultured rat pre-antral follicles. Mol. Reprod. Dev. 58, 287-96. 